\title{
RECONSTRUCTION OF DETENTITON REGULATION AGAINST A SUSPECT OR DEFENDANT IN ACCORDANCE WITH CIVIL CODE BASED ON JUSTICE
}

\author{
Muhammad Khambali \\ hmkhambali@yahoo.com \\ Lecture at Law Faculty of Cokroaminoto University, Yogyakarta
}

\begin{abstract}
Detention is a criminal act of deprivation of freedom which is one of the criminal forms stipulated in the Criminal Code. The mechanisms of detention have been organized according to the Criminal Procedure Code. Mistakes in detention can lead to fatalities for many parties including people who execute the detention. The impact of detention on suspects/defendants is not only felt by suspects/defendants, but also it is felt by families of suspects/defendants, communities, and countries.
\end{abstract}

\section{Keywords: Detention, Suspect/Defendant, Justice}

\section{A. INTRODUCTION}

After 72 years of independent state of Indonesia, there are still many laws of the Netherlands used in this country. For instance, in material law still use the Criminal Code derived from Wetboek van Straafrecht (WvS), whereas this book in the Netherlands has been repeatedly revised.

To enforce the material criminal law requires formal law (criminal procedure law). Before the entry into force of the Criminal Procedure Code, the formal criminal law is HIR as a guideline in the District Court in both civil cases and civilian criminal cases in Java and Madura. For the District Court outside Java and Madura apply RBg or Reglemen of Law Procedure for areas outside Java and Madura. 
The Criminal Procedure Code expressly decides to revoke Het HerzieneInlandschReglement (Staatsblad Year 1941 Number 44) relating to Law Number 1 Drt of 1951 (State Gazette of 1951 Number 9, Supplement to the State Gazette Number 81 ) and all its implementing regulations, in other statutory regulations, with limited provisions regarding the criminal procedural law.I law.

In the Civil Code has laid the foundations of humanism and it is a new era in the judicial environment in Indonesia. The Criminal Procedure Code is a national criminal procedure which is based on the philosophy of Pancasila and the 1945 Constitution.

At the beginning of the Criminal Procedure Code, the Indonesian nation was very proud of the creation of the codification and unification of the national criminal procedure law. Especially with some advantages compared with the previous HIR, the presence of Civil Code has given great hope for the realization of criminal law enforcement that is more effective, fair, and upholds the dignity of human beings. Therefore, it is not surprising that at the beginning of the enactment of the Criminal Procedure Code (KUHAP) was mentioned among the observers of the law as the "masterpiece" of the Indonesian nation. ${ }^{1}$

In the case of the detention to the suspect or the defendant in criminal procedure law has a weakness, so the investigator is too easy to decide to hold someone. Investigators are still using maximum retention mechanisms to the maximum extent of detention allowed by legislation even if they have found sufficient evidence. This resulted in places of detention in Indonesia full and over capacity. The detention should be the last alternative of a suspect or a defendant a crime.

\footnotetext{
${ }^{1}$ Al. Wisnubroto \& G. Widiartana, Pembaharuan Hukum Acara Pidana, Citra Aditya Bakti, Bandung, 2005, page. 3 .
} 
Detention, which in principle is a restriction on human rights, conducted by investigators and prosecutors without a court of law, makes detention difficult to control. The practice of transferring types of detention and also the suspension of detention using the services of lawyers (advocates) is often also aggravated. It is because of the subjective reason that the authorities authorized to hold the detention are concerned on the suspect or defendant is uncooperative at the time of the examination, so that the arbitrary official in detention overrides the request for the transfer of detention or suspension of detention.

Detention is a form of deprivation of one's freedom of movement. In the detention there is a conflict between two principles: the right of one's human rights which must be respected on the one hand, and the interests of public order on the other side which must be maintained for the people or society of the criminal acts of the suspect or defendant. Therefore, detention should be done if it is urgently needed. The fallacy in detention can lead to fatalities for many parties including executors. ${ }^{2}$

Officials authorized to do or not to undertake detention, transfer of types of detention, and suspension of detention of a suspect or defendant are in an institution, it gives the authorities the opportunity to withhold, transfer the type of detention, suspend the detention by irregularities by detention against suspects or defendants arbitrarily or even beyond the authority.

Based on the background for the above research, the writer formulated several problems as follows:

1. What are the factors led to the detention of the suspect or the defendant not bringing justice?

${ }^{2}$ Andi Hamzah, Hukum Acara Pidana Indonesia, Sinar Grafika, Jakarta, 2001, page. 127. 
2. What is the impact of detention on a suspect or a defendant who does not bring justice?

3. How to reconstruct the detention or suspect's rule in the Criminal Code based on the value of justice?

\section{B. RESEARCH METHODS}

The paradigm used in this research is constructivism paradigm. The paradigm of constructivism emphasizes the knowledge gained from experience or research which is then constructed to the extent of the experience or research it has. This type of research is a social legal research. In socio legal research the law is not only conceived as the whole principles and rules governing human life in society, but includes also institutions and processes that realize the application of those norms in society, as the embodiment of symbolic meanings of social actors, as manifested and listened to in and from the actions and interactions between them. ${ }^{3}$

The nature of the research in this study is the analytical descriptive that describes the rules applicable (law positive) associated with the theory of law and its implementation in the life of society. This study used primary and secondary data sources, obtained through literature studies and field studies, which were then analyzed descriptively qualitatively.

\section{RESULTS AND DISCUSSION}

\footnotetext{
${ }^{3}$ Soetandyo Wignjosoebroto, Silabus Metode Penelitian Hukum, Program Pascasarjana Universitas Airlangga, Surabaya, Tanpa Tahun, page 1-3.
} 
1. Factors that cause detention of a suspect or a defendant do not bring about justice;

Detention is deprivation of someone's independence. In the case of this detention there is a contradiction between two principles, namely the principle of the right to move as a human right which must be respected on the one hand and the interests of public order on the other that must be held for the people or society of the criminal acts of the suspect. Criminal procedural provisions may exclude universally recognized principles, namely human rights, in particular the right of individual freedoms. ${ }^{4}$

Suspects or defendants may submit a request for suspension of detention to a detention official. Officials authorized to detain suspects or defendants are similar to those authorized to grant incarceration of detention. This may provide an opportunity for authorized officials to "trade" (commodification) in the suspension of detention.

Suspension of detention can be done with or without money security or guarantee of person. It is clear that the "conditions" referred to in Article 31 of the Criminal Procedure Code are not related to the issue of guarantees and criteria to be granted or not to request suspension of detention ${ }^{5}$. However, requests for suspension of new detentions will be considered if there is a guarantee of money or collateral. If the competent authority requires the suspension of detention with a guarantee of a specified amount of money on the basis of the willingness of the competent authority, the defendant or the defendant is poor cannot fulfill it.

${ }^{4}$ Andi Hamzah, op.cit., page. 3 .

${ }^{5}$ Al. Wisnubroto \& G. Widiartana, op.cit., page. 47. 
Poor situation and conditions in detention houses or other places used to arrest suspects or defendants in Indonesia can now be said to be in an acute over crowded condition. This situation eventually led to various health problems experienced by the prisoners. Not only health issues, but the pretrial detention application also raises a variety of other issues such as the opening up of the possibility of commodification practices as well as fights between prisoners or detention groups. In addition, limited supervision of the judiciary through pretrial mechanisms against investigative institutions makes arbitrary acts often occur against detainees in the form of torture, whether physical or psychic, during the investigation process. There are two main causes of this situation: ${ }^{6}$

1. There is no court supervision (judicial scrutiny) in every stage contained in the current KUHAP (Criminal Procedure Code);

2. The absence of a deep elaboration of the legal requirements of detention as contained in Article 21 of the Criminal Procedure Code.

Factors causing the detention of a suspect or a defendant did not bring about justice due to the non-fulfillment of the rights of the suspect or defendant and not the courage of law enforcement to enforce the law with progressive legal paradigm, among others as follows:

1. The rules of detention of suspects or defendants which have weaknesses (vague) as Article 21 paragraph (1) of the Criminal Procedure Code make the authorities authorized to make easy decisions to hold someone arrested;

2. Officials in charge of detention shall use the mechanism of detention to the maximum extent of detention limits allowed by the Criminal Procedure Code;

${ }^{6} \mathrm{http}: / /$ www.icjr.or.id/praperadilan-di-indonesia-teori-sejarah-dan-praktiknya/accessed on 26-12-2016 at 21.00 WIB. 
3. The mechanism of transferring the type of detention of a suspect or defendant residing on the same official makes the official's subjectivity very crucial in the proclamation or inefficiency of the shifting type transfer;

4. The mechanism of suspension of detention of a suspect or defendant residing on the same official makes the officer's subjectivity very decisive in granting or not requesting the suspension of detention;

5. Guarantees in the request for the suspension of detention in the form of money provide an opportunity for the competent authority to withstand the tendency to hold detention in the hope of the defendant or the accused to file a request for suspension of detention;

6. Guarantees in the request for the suspension of detention in the form of money provide an opportunity to the competent authority to hold a suspension of detention for the commission of suspension of detention;

7. The money security required in the request for suspension of detention is unlikely to be satisfied by a suspect or defendant;

8. The existence of vacuum in the KUHAP does not recognize the existence of judicial scrutiny (judicial supervision) other than prejudicial mechanism as regulated in Article 77 of KUHAP;

9. Poor situation and condition in over-crowded houses raises a variety of health problems, the practice of commodification as well as inter-resistance fighting;

10. Law enforcement practices are still legalistic positivism. The way of thinking used is to spell laws and obey procedures by ignoring the value of subsistence justice, as well as abandoning the language of conscience. Law enforcement districts that their work requires a 
dynastic, so the law is used as a doctor's stethoscope. Legal practice becomes a more busy practice of operating rule and logic rather than wondering whether the function of law in society is well under way. When that happens, it has actually been trapped into the notion of "man for the law", and if law enforcement officers hold to the belief that man is a law, then man will always be cultivated or may be forced to enter into the schemes that have been made by law. So it appears that "justice over rules / procedures". ${ }^{7}$

2. The impact of detention on suspects or defendants which do not bring about justice;

Detention of a suspect or defendant, even as a form of law enforcement, has a negative impact on the individual suspect or defendant, family, community, or country. The impact can be social, economic, psychological, job losses, contracting illness, and so on. The defense of suspects or defendants in accordance with the rules also has a negative impact, moreover the detention of suspects or defendants who violate the rules, arbitrary, and does not bring about justice.

Detention of a suspect or defendant is as a time period in which an individual is deprived of his or her freedom. Detention of suspects or defendants may be conducted from the investigation level to the reading of court judgments at the first level (District Court), appellate level (High Court), or cassation level (Supreme Court).

Excessive and arbitrary pre-trial detention is one of the most neglected forms of human rights abuses that affect millions of people each

${ }^{7}$ http://polisi-sholeh.blogspot.com/2009/07/hukum.html. accessed on 13-12-2016 at 20.00 WIB. 
year, causing and aggravating poverty, hampering economic development, spreading disease, and weakening the rule of law. Pre-trial detainees may lose their jobs and residence; exposed to the disease and spread the disease; are required to pay bribes to obtain freedom or better conditions of detention; and suffered long-lasting physical and mental disorders once their detention period has ended.

The decision to detain a person before he or she is found guilty of a crime is one of the toughest decisions a country or individual can take. Decisions made instantly by the arresting officer will have a profound and lasting negative impact.

A large number of suspects or defendants held in custody are vulnerable to torture, extortion and disease attacks. They become victims of arbitrary action from officials, corrupt officials, and even from other detainees. They also have only limited information about their human rights.

Suspected suspects or defendants may lose their jobs, and are forced to abandon their families. They are exposed to illness and suffer from physical and mental disorders once their period of detention has ended. Their families also suffer from loss of income and opportunities for education. The multi-generational impact is the children of the prisoners experienced decrease in their education. Excessive pre-trial detention (suspects or defendants) pushes people toward poverty. This encourages prisoners to become unemployed, in uncertainty and increasingly in poverty. This situation also makes people who already live in poverty slumped in to a more severe poverty. It also impedes the development of 
society as a whole, wastes human potential, and makes state resources deviate from its proper direction. ${ }^{8}$

Many of the bad consequences caused by the use of detention of suspects or defendants are excessive. Negative impacts of detention on suspects or defendants which did not bring about justice, among others: suspects or defendants lost employment opportunities; suspect or defendant is exposed to factors that encourage chromogenic acts; suspects or defendants are vulnerable to torture, extortion and disease; suspects or defendants who have lost their jobs; suspects or defendants are forced to abandon their children's education, even forced to sell assets for sale to finance life and face cases facing a suspect or defendant; as well as stigma as a criminal (criminal) attached to the suspect or defendant in public.

The socioeconomic impact of detention on suspects or defendants is not only experienced by suspects or defendants themselves, but affects their families because of the loss of jobs and income as a result of excessive detention. The impact is very hard to deal with in poor and developing countries where the state does not provide reliable financial aid to the poor and it is not unusual for a family member to become a support in funding the whole family.

Impact of detention on suspects or defendants for families, among others: disruption of the family economy that tends to lead to poverty; families must work hard to survive; children's education is disrupted (failing school); the need for increased expenditure on accommodation, legal fees, and sometimes even the cost of "bribes"; families have the

\footnotetext{
${ }^{8}$ https://komitekuhap.files.wordpress.com/2012/06/dampak-sosial-ekonomi-pena hanan.pdf Open Society Justice Initiative, Dampak Sosial Ekonomi Dari Penahanan Pra-Persidangan, Open Society Foundations,New York USA, 2010, page. 10.
} 
potential to contract the disease of the suspect or defendant; and alienated by the community environment.

Impacts of detention on suspects or defendants for the community, among others: the community in which the suspect or defendant resides is labeled a criminal society as well as contracting the illness brought by the accused or defendant. For the state, any detention of a suspect or defendant means increased expenses (direct costs), reduced revenues (indirect costs) and depleting resources for other programs (opportunity costs).

3. Reconstruction of detention rules against suspects or defendants in Criminal Procedure Code based on justice value.

Reconstruction of a suspect or defendant based on a dignified justice value judgment by amending, supplementing, or refining articles containing the rules or conditions of detention, as follows:

a. Article 21 paragraph (1) of KUHAP, after reconstruction, the formula is :

Detention or further extension of detention or continued detention of a suspect or defendant who are suspected of committing a crime on the basis of sufficient evidence and allegedly suspects or defendants will:
a. Escape;
b. Damage or eliminate evidence and / or evidence;
c. Affect witnesses;
d. Commit a crime;
e. Threaten his safety and with the consent or request of the suspect or defendant. 
b. Article 21 paragraph (4) of KUHAP, after reconstruction, the formula is :

Such detention may only be imposed on suspects or defendants committing criminal acts and/or trials or providing assistance in such acts in the event of:

a. The offense is punishable by imprisonment of 5 years or more;

b. Criminal acts referred to in Article 282 paragraph (3), Article 296, Article 335 paragraph (1), Article 351 paragraph (1), Article 353 paragraph (1), Article 372, Article 378, Article 379 a, Article 453, Article 454, Article 455, Article 459, Article 480 and Article 506 of the Criminal Code, Article 25 and Article 26 of Rechtenordonnantie (violation of the Customs and Excise Ordinance, finally amended by Staatsblad Year 1931 Number 471), Article 1, Article 2 and Article 4 Immigration Crime Act (Act No. 8 of 1955, State Gazette Year 1955 Number 8), Article 36 Paragraph (7), Article 41, Article 42, Article 43, Article 47 and Article 48 of Law Number 9 Year 1976 on Narcotics (State Gazette Year 1976 Number 37, Supplement to State Gazette Number 3086);

c. The suspect or defendant has no permanent residence and/or unclear identity, even if a suspected/criminal offense is threatened with imprisonment of less than 5 years.

c. Article 23 paragraph (1) of KUHAP, after the reconstruction of the formula: 
At the request of the suspect or defendant the judge of the commissioner may transfer one type of detention to another type of detention as referred to in Article 22.

d. Article 24 paragraph (1) of KUHAP, after the reconstruction of the formula:

The order of detention granted by the investigator as referred to in Article 20 shall be made for a maximum period of 10 days.

e. Article 24 paragraph (2) of KUHAP, after the reconstruction of the formula:

The period as referred to in paragraph (1) where required for the interest of unfinished examination may be extended by the commissioner's judge upon the investigator's request for a maximum of 14 days.

f. Article 25 paragraph (1) of KUHAP, after reconstruction of the formula:

The order of detention granted by the public prosecutor as referred to in Article 20 shall only be valid for a maximum of 7 days.

g. Article 25 paragraph (2) of KUHAP, after the reconstruction of the formula:

The period as referred to in paragraph (1) where required for the interest of unfinished examination may be extended by the judge commissioner at the request of the public prosecutor for a maximum of 14 days.

h. Article 26 paragraph (1) of KUHAP, after reconstruction of the formula: 
The judge of the district court adjudicating the case referred to in Article 84, for the purpose of arbitrary examination shall issue a further detention order for a maximum of 60 days.

i. Article 26 paragraph (2) of KUHAP, after the reconstruction of the formula:

The period referred to in paragraph (1) if required for the purposes of the unfinished examination may be extended by the respective head of the district court for a maximum of 60 days.

j. Article 27 paragraph (1) of KUHAP, after the reconstruction of the formula:

The high court judge who adjudicates the case as referred to in Article 87, for the purpose of arbitrary examination shall issue a further detention order for a maximum of 30 days.

k. Article 27 paragraph (2) of KUHAP, after the reconstruction of the formula:

The period referred to in paragraph (1) if required for the purposes of the unfinished examination may be extended by the relevant High Court Speaker for a maximum of 30 days.

I. Article 28 paragraph (1) of KUHAP, after the reconstruction of the formula:

The judge of the Supreme Court adjudicating the case referred to in Article 88, for the purposes of the examination is authorized to issue a further detention order for a maximum of 30 days. 
m. Article 28 paragraph (2) of KUHAP, after the reconstruction of the formula:

The period referred to in paragraph (1) if required for the purposes of the unfinished examination may be extended by the Chief Justice of the Supreme Court for a maximum of 60 days.

n. Article 29 paragraph (1) letter a of KUHAP, after the reconstruction of its formula:

No reconstruction. Researchers propose Article 29 paragraph (1) letter a KUHAP removed.

o. Article 31 paragraph (1) of KUHAP, after reconstruction of the formula:

At the request of the suspect or defendant the judge of the commissioner may suspend his or her detention with the money and / or guarantees on the condition specified.

p. Article 31 paragraph (2) of KUHAP, after the reconstruction of the formula:

Since his position as a commissioner judge may at any time be able to remove suspension of detention in the event of a suspect or a defendant violating the requirements referred to in paragraph (1).

q. Article 77 of KUHAP, after the reconstruction of the formula:

Commissioner Judges are authorized to examine and decide upon, in accordance with the provisions of this Law regarding:

a. The need or absence and validity of arrest, detention, suspension of investigation or termination of claim. 
r. Article 123 paragraph (1) of KUHAP, after reconstruction of the formula:

The suspect, family or legal counsel may object to the detention or type of detention of the suspect to the judge commissioner.

s. Article 123 paragraph (2) of KUHAP, after the reconstruction of the formula:

Therefore, the Commissioner Judges may grant the request by considering whether or not the suspect should remain in custody or remain in certain types of retention.

t. Furthermore, the researcher submitted an additional article regarding the judges of the commissioners to be included in the Criminal Procedure Code, as follows:

(1) The judge of the commissioner shall be an officer authorized to assess the course of the investigation and prosecution, and other authorizations provided for in this Law.

(2) The Judge of the Commissioner or Judge of the Preliminary Examiner is authorized to determine or decide:

a. The need/absence or validity of arrest, detention, search, seizure, or wiretapping;

b. Cancellation or suspension of detention;

c. That the statements made by a suspect or a defendant by infringing the right not to offend themselves;

d. Illicit evidence or statements obtained cannot be used as evidence;

e. Replace damages and/or rehabilitation for a person arrested or illegally detained or compensation for any unlawfully seized property rights; 
f. The suspect or defendant is entitled to or is required to be accompanied by a legal counsel;

g. That an investigation or prosecution has been committed for an unlawful purpose;

h. Termination of investigation or cessation of prosecution not based on the principle of opportunity;

i. Whether or not a case is required for prosecution;

j. Violation of any other suspect rights that occurred during the investigation stage.

\section{CONCLUSION}

\section{Summary}

a. Factors causing the detention of suspects or defendants do not bring about justice, including: (i) the rules of detention have weaknesses (vague) as Article 21 paragraph (1) of Criminal Procedure Code, so that an arbitrary official may decide to hold someone, (ii) the mechanism of detention is carried out to the maximum extent of the detention limit permitted by the Criminal Procedure Code; (iii) the official subjects are crucial in granting or applying for the transfer of type of detention; (iv) the official subjects are critical in granting demand the suspension of detention, ( $v$ ) the guarantee of the suspension of a custody in the form of money provides an opportunity for the competent authority to hold the custody with the expectation of the suspect or the defendant; (vi) the guarantee of the suspension of the detention in the form of money gives an opportunity to the competent authority suspension of detention to carry out co-modification of suspension 
of detention, (vii) ja (viii) Criminal Procedure Code does not recognize judicial scrutiny, (ix) poor situation and condition in overcrowded houses, $(x)$ practices law enforcement is still legalistic positivism;

b. The impact of detention on a defendant or defendant that does not bring about justice is: (i) for the suspect or defendant: loss of employment; exposed to factors that encourage crimogenic acts; vulnerable to torture, extortion, and disease; loss of a job; forced to abandon their children's education, forced to sell assets to pay for life and face the case at hand; stigma as a criminal (criminal) attached; (ii) for the families of suspects or defendants: disruption of the family economy; families must work hard to survive; children's education is disrupted (drop out); the need for increased money for accommodation, legal fees, and "bribe" fees; families potentially contracting the disease, alienated by the community environment; (iii) to society: to be labeled a criminal society; contracting a disease brought by a suspect or defendant; and (iv) for the country: increased expenses (direct costs); lack of income (indirect costs); and depleting resources for other programs (opportunity costs);

c. The reconstruction of the detention of suspects or defendants in the Criminal Code based on the value of justice can be done by reconstructing Article 21 paragraph (1) and paragraph (4), Article 23 paragraph (1), Article 24 paragraph (1) and paragraph (2), Article 25 paragraph (1) and paragraph (2), Article 26 paragraph (1) and paragraph (2), Article 27 paragraph (1) and paragraph (2), Article 28 paragraph (1) and paragraph (2), Article 29 paragraph ( 1) a, Article 31 Paragraph (1) and Paragraph (2), Article 77, Article 123 Paragraph (1) and Paragraph (2) of the Criminal Procedure 
Code, and may be added to the Judge Commissioner for inclusion in the Criminal Procedure Code.

\section{Suggestions}

a. In conducting of detention of suspects or defendants must remain in a way of "humanize man"

b. Detention of a suspect or defendant should be used if there is no other option to address the risk of the suspect or the defendant fleeing or harming the public;

c. The use of the deposit as far as possible should be avoided, as suspects or defendants who come from among the poor will find it difficult to provide money to pay guarantees to authorized officials.

\section{References}

\section{A. Books}

Al. Wisnubroto \& G. Widiartana, Pembaharuan Hukum Acara Pidana, Citra Aditya Bakti, Bandung, 2005.

Andi Hamzah, Hukum Acara Pidana Indonesia, Sinar Grafika, Jakarta, 2001.

Soetandyo Wignjosoebroto, Silabus Metode Penelitian Hukum, Program Pascasarjana Universitas Airlangga, Surabaya, Tanpa Tahun.

\section{B. Internet :}

http://www.icjr.or.id/praperadilan-di-indonesia-teori-sejarah-danpraktiknya/di-akses pada tanggal 26-12-2016 pukul 21.00 WIB.

http://polisi-sholeh.blogspot.com/2009/07/hukum.html. diakses 13-122016 pukul 20.00 WIB.

https://komitekuhap.files.wordpress.com/2012/06/dampak-sosialekonomi-penahanan.pdf Open Society Justice Initiative, Dampak Sosial Ekonomi Dari Penahanan Pra-Persidangan, Open Society Foundations,New York USA, 2010. 